\title{
Geography of Insurgency-Contextualization of Ethno-Nationalism in Northeast India
}

\author{
Leishipem Khamrang \\ Royal Thimphu College, Thimphu, Bhutan \\ Email: apemkhamrang@yahoo.com
}

Received 7 May 2015; accepted 8 June 2015; published 11 June 2015

Copyright (C) 2015 by author and Scientific Research Publishing Inc.

This work is licensed under the Creative Commons Attribution International License (CC BY). http://creativecommons.org/licenses/by/4.0/

(c) (i) Open Access

\begin{abstract}
Northeast India has been plagued by insurgency related violence and conflicts for many decades. The greater threat and concern have been, however, the rising regional tensions albeit promulgation of series of insurgency crack-down policies by successive central and state governments since the 1950s. To contain insurgency activities, new winning formulas have been announced occasionally, promising incentives or job to the surrenderees, with events of surrendering insurgent's ceremonies yet several newer insurgents and splinter groups have been formed. The volatile state power relations intrigue the entire geopolitical condition and create space for development of newer geographical landscape of conflict thereby turning the region to one of the most sensitive regions in India. The paper is an attempt to examine the emergence of insurgency movements, the nature of contextualization insurgency activities and spatial conflict in Northeast India in the backdrop of the contesting state power relation.
\end{abstract}

\section{Keywords}

Ethno-Nationalism, Northeast India, Insurgency, Spatial Conflict, Violence

\section{Introduction}

Violence and conflict have been a traditional theme within political geography and geographers have been consistently arguing that violence and conflict, including insurgencies, are inherently geographic as they occur in particular place [1] and across geographical territory. Territories in Northeast India are demarcated by contradictory superimposed boundaries - modern state boundaries over traditional boundaries. Historically, traditional boundaries coincide with the ethnic mapping. Such ethnic territorial identity has been blatantly ignored during the reorganization of states in the post independence. Territorial politics, revolving round between these two entities — modern and traditional boundaries, compound regional conflict with many ethnic groups asserted to restore 
the traditional boundaries; the case of Naga represents an appropriate example. Nagas are one, therefore, construct of sub-naga identity, such as, Manipur Nagas, Nagaland Nagas, Assam Nagas etc., within the federal set up, and Constitution of India is vehemently opposed by the Nagas. Division of Naga inhabited areas into different states of India is merely a scheme inducted to neutralize the Naga movements for independence-movement that was begun before the independence of India. In the last few decades, new trends of conflict have emerged following the intrusion of neoliberalism undermining the effective indigenous mode of production. The problems of the regions are no longer of conventional social and economic practices but inherently link to the modern statist version of development policies initiated. The statist version of development policies restructures the organic relation of the community, dissociates them from the conventional material practices and gradually pushes them into the unfamiliar new economic system. The material practices of communities are systematically getting exposed to a process of contrasting imagination constructed by the state through projects of neo-liberal capitalist territorialization. The capitalist and the statist logics are, therefore, found overextending themselves to subjugate the organic practices from below [2] thereby creating newer spaces of conflict continually. The contesting state power relation thus becomes inherently a factor of spatial conflict. The state deploys military force in an attempt to overawe native opponents, but for the native who cannot accept state policy, insurgency became the politics of last resort [3]. It is quite comprehensible that the underlying causes of conflicts and insurrection of armed insurgent in the region are intrinsically linked to Central's apathy towards the unique traditional socioeconomic and political system of varied indigenous communities, and lack of understanding, recognition and acceptance of mainland Indian to the people of the region. This is often contested by the statist agents who asserted underdevelopment and isolation of the region as a result of insurgent activities and persistent internal ethnic conflicts. However, failure to integrate the region with the mainland, socially, politically and economically during the last 60 years of the plan period substantiates the fact that the problem of the region cannot be viewed from the mainland Indian perspective- which often negates the indigenous development praxis. The whole development scenario thus creates space for significant debate which demands for proper understanding of the societies at the grassroots. The present paper embarks mainly on understanding the causes underpinning the dichotomy of state power relation and resulted fragmented space of conflict.

\section{Free India and the Birth of Insurgent Movements in Northeast India}

Insurgency is not a new phenomenon in the history of mankind while in India it emerged mainly during the 1950s following consolidation, by consent or force, of several erstwhile princely states into modern India. India in its entire history, until colonized by the British and united at gun point, was never a single nation [4]. After the colonial rule, India succeeded in consolidation of many regions and provinces yet failed to conquer the hearts of many people particularly in the Northeast. India could conquer the land but not the hearts of the people. For the people of this region, range from small fiefdoms to large princely states and who had for centuries enjoyed independent existence, this administrative and political amalgam amounted to loss of identity and freedom. Besides, the new dispensation—democracy, in many cases brought no political or economic advantage [4]. The post Independence era thus opened new chapter of armed insurgents in the history of India.

Insurgency activities in Northeast India grew out of varied reasons and purposes with each of them having different agendas but a single thread runs through them all is the construction of homeland. Unlike other insurgent groups in India, the various insurgency movements in Northeast established basic ingredients for continued insurrection, namely, territorial and community-based group. These groups are armed, politically as well as militarily organized, while some of the movements are politically oriented towards the overthrow of present government. Emergence of such "groups politico-territorial identities" vying for separate territory within or outside India [5] has escalated regional conflict. Since most of these insurgent groups are territorial and community based-group, civil societies and insurgents together challenge the construct of Indian nationhood taking the pre-independent era as reference period where many parts of the region were independent under different form of governances. The tribal communities have their own form of governance (republic) while the valley dwellers like the Ahom, Kacharis, Meitei etc., are known for well-established kingdoms under monarchy system [6]. The term secessionist movement labeled against them is therefore discarded outright by many and asserted their movements as legitimate - to restore the lost territory which they held before the advent of the British.

The continued mass based insurgents grow stronger while some of the frontal civil organizations are even labeled as mouth piece of insurgents group. Civil organizations and insurgents are literally two sides of the same 
coin, merely existing in different form with different responsibilities, having common goal of reconstruction of homeland. Historically speaking, many insurgent activities in the regions starts off as a resistance movement which is an organized effort by some portion of the civil population to resist the legally established government or the occupying power to disrupt the civil order and stability [7]. Insurgents cannot exist without support of the people. Insurgency activities, therefore, still remain active in Northeast in spite of several efforts accorded by Central government to stabilize the situation. Even deployment of several paramilitary military forces under the provision of Armed Special Power Act could not subdue the problems in the last 65 years.

Ethnic groups in the region are bonded by their socio-cultural and political entity therefore any external forces that disturb this cultural cohesion is bound to have severe repercussion. Apparently, unimaginative states' responses have intensified regional tensions as experienced since the 1950s and against this backdrop, several armed resistance movements have been given birth. This was the period when armed insurrection emerged in Nagaland, using the remnant weapons of the Second World War. The battle at Kohima, fought between the British and Japanese forces, may be considered as the last battle of the allied forces in Indian soil but it opened the new path of armed insurrection in Nagaland. During the Second World War, insurgents and guerilla movements were established with the support of allied forces in Asia, North Africa and continental Europe while armed insurrection as a mean of political change was legitimized [8]. Involvement of allied forces may not be very relevant as far as the birth of insurgent in Northeast India is concerned. However, one cannot undermine how the father of Naga Nation: Zaphu Phizo and his brother Kevi Yalley joined Bose's INA to fight against the British with a hope that Naga Hills would be a free nation after the British left India. Severe battle took place at Kohima between Japanese division supported by thousands of Bose's INA troops and the British army. At the end of the war, Phizo was arrested by the British in Rangoon and served for seven months imprisonment when Rangoon was captured in May 1944. On his returned to Nagaland, he propagated for free Nagaland. Since then, the geopolitics of the Northeast took a new turns.

The beginning of Independence era took a new turn in Indian history with many armed rebellion groups rose against the state. Interestingly, one of the last conquered tracts of the colonial regime (Naga Hills) emerged as a place where the first armed rebellion group was formed in the sub-continent. In fact nationalism is not recent development; the Ahoms, who ruled Assam for several centuries, fought back the invading Mughals. The Manikya Kings of Tripura fought the Bengal Sultans back from the hill region and conquered eastern Bengal. The Burmese were the only ones who overran Assam and Manipur [9]. The Nagas and the Lushais resisted strongly against intrusion of the British into their territories and many British were got killed. The idea of resistance continued even during the colonial regime. The Nupilan (Women's war in Manipur) in 1904, the Kuki rebellion of 1917-1919, uprising of Zeliangrong under the leadership of Haipaou Jadanong in the 1920s, formation of Naga Club, etc., are significant markers of resistance movement. After Independence of India, central's attitude towards these resistance groups changed, giving emphasis on complete annihilation of the separatist movements with the military might. British's military policy, "Armed Special Power Act” to quell quite India movement, was therefore reinforced in Northeast India but during these 65 years long of military regime, several number of insurgency groups have been formed, putting the success story of military rule under severe criticism from the civil societies.

\section{National Consciousness and the Rise of Sub-Nationalist Movement-State Wise Scenario}

The rise of sub-nationalist movements and increased socio-political self-assertion by the minority communities has generated waves of unprecedented violence and conflict in the region. The birth of insurgency in Northeast India is a manifestation of revitalization of historical construct of a nation prevailed prior to the establishment of colonial regime. The Nagas were the first to challenge the India nationhood in the post independence. Naga nationalism is as old as the history of Nagas. Naga had resisted against intrusion of several forces at different point of times in the past even before the advent of the colonial rulers. The construct of Pan-Naga nation evolved out of political, territorial and social consciousness which eventually led to the formation of Naga club in 1918. This was a significant event in the history of Naga resistance movement representing the first organized political movement in Northeast India. The Naga club submitted a memorandum to the British Simon Commission in 1929 stating that Nagas should be left alone should the British leave India. Therefore, question of "uprising against constituted Government” does not arise as a free Indian State had not been then established [10]. 
The construct of Naga nationalism and Naga identity grew stronger with the formation of Naga National Council (NNC) in 1946. The Naga National Council was formed as the representative of Nagas which set out to construct a national identity by "othering” the Indians [11] and the organization's goal was the unification of all Naga tribes [12]. NNC declared independence of Nagaland on $14^{\text {th }}$ August, 1947 and intimated the same to the Government of India and to the United Nations Organization. Under the leadership of A.Z. Phizo, NNC gained momentum after referendum, popularly known as the Naga Plebiscite, was conducted on 16 May, 1951 where 99.9 percent voted for independence of Nagaland. In 1952, the NNC boycotted India's first general election and launched civil disobedience movement; refrained from paying tax to Indian government and set up its own schools. The situation grew tenser with the movement of NNC become more radicalized while the India government opted to neutralize the situation with repressive military measures. Arrest warrant was ordered against the NNC members, forcing them to take refuge in the jungle. Subsequently, a large number of Indian Armies were deployed in Naga Hills in 1953 and massive crackdown on NNC was launched.

Atrocity of Indian Army was first committed when two villagers (Beechatami and Lopeelu Tami) were killed and their bodies were tied with ropes and dragged in the street of Kohima by the police to put fear in the minds of the onlookers in the aftermath of Nagas leaving en masse few minutes before the delivery of speech by Indian Prime Minister Jawaharlar Nehru in 1953 at Kohima local ground. This was followed by massacre of 57 people of Impang village by Pangsha villagers in Tuensang division of the North East Frontier Agency in 1954. It was found out later that Indian Intelligence Bureau incited the villagers of Pangsha to attack Impang village, to avenge the death of one postal worker killed by Impang villagers. However, the hidden strategy was to eliminate some of the NNC members encamped at Impang village [13]. All these incidents did not deter Nagas from their demand for homeland rather it fueled their angers. Nagas gradually understood the intention and policies of the Indian government towards the Nagas. Subsequently, NNC declared setting up of an underground Naga government on September 18, 1954 [13]. In the early 1955, Makokchung was declared a "disturbed area" and later in 1956 the entire Naga Hills was declared as "disturbed area". NNC embraced arms as the last resort to counter the India military might rather surrendering the rights of the Nagas. On March 22, 1956, NNC formed an underground government called the Naga Federal Government (NFG) and a Naga Federal Army (NFA) was created. Since then Northeast India has been passing through insurgencies of various types and India has been confronting with tenacious insurgency in the region. The number of outfits multiplied over the years each one with own agenda.

By 1956, the NNC's guerrilla consisted of 5000 men, equipped with traditional spears and daos as well as weapons left over from World War II [14]. Without any internal crisis the movement carried on until Shillong Accord was signed on November 11, 1975 between Indian Government and few signatories from NNC. The darkest period in the annals of Nagas' movement for self-determination came with the signing of Shillong Accord. With the help of Indian Government, NNC staged a coup and attacked the patriots who denounced the Accord. Those who upheld the Shillong Accord brought on division amongst Nagas and they are responsible for fratricide killing [15]. There were, however, few hardcore nationalists who strongly denounced the Accord. IsakChishiSwu and ThuingalengMuivah who had established base in Myanmar-Naga territory since March, 1975 along with the armies who returned from China did their best to convince A.Z. Phizo and some of their colleagues [16]. After five years of vain effort to sort out the matter with the then president of NNC, Mr.A.Z. Phizo, National Socialist Council of Nagaland (NSCN) was formed with Isak Chisi Swu as Chairman, Thuingaleng Muivah as General Secretary and S.S Khaplang as Vice President on January 30, 1980. NSCN also established Government of the People's Republic of Nagaland. NSCN further split into two factions in 1988, one faction (NSCN-IM) led by Isak Chishi Swu and Thuingaleng Muivah and the other faction (NSCN-K) led by S.S. Khaplang. Government of India entered into ceasefire agreement with NSCN-IM in 1997 and several rounds of talks have been held without any significant outcome. The political impasse and lackluster progress in negotiation between the Government of India and Naga insurgent outfits eventually has compelled some insurgent leaders to search for more coercive alternative measures having no faith in political dialogue. Recently, NSCN-K has abrogated ceasefire agreement with the Government of India and constant threat from NSCN-IM to end the ongoing ceasefire agreement with the Government of India against futile outcome of political negotiation places the entire political situation at stake.

In Manipur, resistance movement against the British first took place in 1904. A popular movement called Nupi Lan (women's war) was launched against the oppressive economic and administrative policies of the colonial power. The first Meitei armed insurrection was however, started by Hijam Irabot in 1950s against the merger of 
Manipur Kingdom with Indian Union on 15 October, 1949. Hijam Irabot and his fellow revolutionaries formed the "Red Guards" to resist against the Indian state. Inspired by Marxist ideology which he gained during his prison life in Sylhet jail, his main aim was to established an Independent Peasant Republic" in Manipur. However, unable to establish liberated zones inside Manipur, he went to Burma and secured support from insurgent Communist Party of Burma. Unfortunately, Irabot died of typhoid at his headquarter in Kabaw Valley on 26 September 1951 and the first revolutionary movement of the Meitei also ended after his death [14]). Armed insurrection reemerged in Manipur when United National Liberation Front (UNLF) was formed on $24^{\text {th }}$ November 1964. Gradually, several factions emerged due to leadership and ideological crisis within the outfit. Apart from UNLF, People's Liberation Army (PLA) was founded on $25^{\text {th }}$ September 1978, People's Revolutionary Party of Kangleipak (PREPAK) was set up on October 9, 1977 and the Kangleipak Communist Party (KCP) came into being in April, 1980. Many smaller groups emerged but in spite of indifference in party's ideology, restoration of the lost Kingdom of Manipur is their main and common agenda.

In Assam, resistance movement against illegal migrants have taken toll of several lives and displaced several thousands of people. The root cause of today's problem in Assam is the local people's fear psychosis about others [17] particularly the illegal immigrants. An estimated five million Muslim Bengalis fled to Assam in the wake of the liberation war in East Pakistan (now Bangladesh). Sensing the threat to indigenous population of the state, a group of young men gathered to discuss the state of affairs at Sibsagar's famous Rang Ghar (an amphitheatre constructed by the Ahoms three centuries back). The students began a campaign to expel the state's millions of foreigners, claiming that they has stolen job in paper, tea and oil industries. Worse has been the nexus between the local politician and the illegal migrants where local politicians helped the foreigners get ration cards and other documents which made it possible for them to register as voters. Even today, the situation and practice seem unchanged for wants of vote banks by the politicians. During Assam violence in July, 2012, L.K. Advani slammed Congress that congress's collusion with the massive influx of illegal immigrants from Bangladesh was the root cause of recurring violence in Assam [18]. The issue of immigration is the core of conflicts but transformation of such conflicts into insurgencies with a radical interpretation of their respective histories, in which the India state is considered as an "external agent" [19] poses threat to India's internal and external security. Indeed, the role of foreign hands has been featured frequent in political debates and India has been making a significant attempt to accommodate these issues while looking for economic integration of Asian countries under ambitious Look East Policy.

In the backdrop of movements against influx of illegal migrants, United Liberation Front of Asom (ULFA) was formed on $7^{\text {th }}$ April 1979. In addition to the ULFA insurgency, the largest plains tribes in the State, the Bodos in the 1980s initiated a movement on issues such as dispossession of their tribal lands by Bengali and Assamese settlers as well as apathy shown to the Bodo language and culture by the mainstream Assamese. In 1975, All Bodo Students Union (ABSU) along Bodo Sahitya Sabha launched movement demanding Roman Script in lieu of Assamese Script for Bodo language. In the course of movement, 15 persons were killed and 50,000 Bodo people were arrested [17]. During the ABSU annual conference between $19^{\text {th }}$ to $22^{\text {nd }}$ December 1988 at Basbari, Bodo People's Action Committee (BPAC) was formed and decided to place demand for separate Bodo state. The agitation gradually turned violent as many youth went underground and formed military organization [17] called Bodo Security Forces (BdSF). Later, the nomenclature was changed to National Democratic Front of Bodoland (NDFB). Within the outfit, indifferences occurred and several splinter groups emerged such as, Bodo Volunteer Force (BVF), Bodo Liberation Tigers (BLT), People's Democratic Front (PDF), etc. Negotiations between the government and the militant outfit culminated to the creation of the Bodoland Territorial Council (BTC) in December 2003. Apart from ULFA and the Bodo insurgency, the state has been also affected by insurgent group of Karbi, Dimasa, the Adivasis and also the Islamists. Karbi and Dimasas have demanded autonomy for their homelands whereas the Adivasis have demanded greater recognition of their rights.

Insurgent group was formed in Mizoram out of resentment against the inadequate and untimely response accorded by the Assam government during the infamous famine "mautam" in 1959. In fact the Mizo Hills District Council informed Assam government about the possible outbreak of famine, following flowering of bamboos, to the government of Assam, yet the Chief Minister ridiculed the connection between bamboo flowering, increase in rodents and the consequent famine as tribal belief [14]. When the tragedy hit, state government could not response immediately and effectively compelling local people to swing into action. Large number of voluntary bodies came up to provide relief to the famine stricken people [20]. The Mizo Cultural Society, a social club, was converted into a non-governmental famine relief organization called the Mizo National Famine Front 
(MNFF) by Laldenga. Later in 1961, the word "famine" was dropped and the idea of the organization changed from famine fighting group to independence movement of Lushai Hills. Many young Mizos were recruited and sent them to remote villages to distribute the relief supplies and propagate the new slogan: Mizoram for the Mizos, where Laldenga wanted nothing less than an independent nation of his people. Taking revolutionary stance to liberate Mizos from the new Indian regime, MNF embraced arms to rebel against India. To procure arms, the first batch of MNF volunteers was sent to Chittagong Hill Tracts in East Pakistan [14). On February 28, 1966, the MNF launched "Operation Jericho"-a blitzkrieg operation that led to the capture of eleven towns in Mizo hills in one stroke [21] and declared independent of Mizoram on March 1, 1966. Laldenga and other sixty signatories signed the declaration, which appealed to all independent countries to recognize independent Mizoram. The struggle lasted for 20 years and MNF cadres laid down arms upon signing of the so-called Peace Accord in 1986, technically termed as "memorandum of settlement" [20]. Mizoram was curved out from Assam and granted statehood on 20 February1987, and the outfit leader Laldenga became the first chief minister of the newly created Mizoram state.

Tripura, perhaps, is the lone state in India that had tribal kingdom in the history with more than 1300 years ruled by tribal king before its accession to the union of India in October 1949 [22]. The beginning of organized insurgent activity in the late 1970s in the state was a result of long internal conflict between the illegal immigrants (Bengali from Bangladesh) and the native Tripuris. The incessant influx of illegal migrants during the partition caused drastic change in demographic structure, leading to fierce ethnic conflict ravaged the tiny state for more than three decades [23]. Between 1947 and 1971, more than 600,000 refugees entered the state [22]. The indigenous people in the state, who accounted for 95 per cent of the population of Tripura in the 1931 census, reduced to just 31 per cent at the time of the 1991 census [24]. Large proportion of the immigrants were cultivators resulting to cutting down of vast forest areas for jhum cultivation. This impacted drastic decline in jhum land-population ratio, jhum cycle and its productivity. Many of the native population became landless as their lands were grabbed for rehabilitation for the immigrants. Tribals were pushed to the hills and gradually immigrants dominated the politics and administrations in the state. Socio-economic status of the immigrants also becomes more dominant and tribals were gradually marginalized. The social and economic consciousness gradually developed among the educated tribal youths with increasing number of Bengali bureaucrats and economic marginalization of the tribes. In order to address the educational problems among the tribals, an organization called Jana Shiksa Samity (JSS), the first Tripuri (tribal) pro-nationalist organization, was formed by few educated youths in 1945 [25]. The youth organized themselves under the banner of Communist Party of India to defend their ancestral land but defected from the communist party and formed their own party called Upjati Yuba Samiti (Tribal Youth Party) due to ideological differences. The splinters group subsequently formed a military organization called "Senkrak" to fight for the tribals right and injustice meted out to the tribals thus, become the first extremist group of tribals operating in Tripura [26]. Since then many new outfits have emerged, such as, Tripura National Volunteers (TNV), All Tripura People's Liberation Organization (ATPLO), The National Liberation Front of Tripura (NLFT), All Tripura Tiger Force (ATTF), Borok National Council of Tripura (BNCT).

Insurgency in Meghalaya and Arunachal Pradesh is comparatively recent phenomena. Social, economic and political consciousness of the native population grew stronger with the rising domination of non-tribals, resulted to development of xenophobia amongst the local against the non-tribals. There was a fear among the major indigenous tribes, i.e., the Khasis, the Jaintias and the Garos, being swamped demographically, culturally as well as economically by the non-tribals [27]. Inspired by the logic of "anti-foreigners" agitation in Assam led by All Assam Students Union (AASU) in the 1970s, Khasi Student Union (KSU) spearheaded agitation against the non-tribals with the tacit support of the traditional elites started in the 1980s [28]. It was against the backdrop of tribal-nontribal dichotomy that insurgency movement started with a motive of driving out the "dkhars" (outsiders) from the state. The HynniewtrepAchik Liberation Council (HALC) was formed in 1992 to safeguard the right of the tribals comprise of Khasi, Jaintia and Garos in Meghalaya. The outfit split into two factions: Hynniewtrep National Liberation Council (HNLC), representing the Khasis and the Jaintias, and the Achik Matgrik Liberation Army (AMLA) representing the Garos. The AMLA subsequently passed into oblivion to be replaced by the Achik National Volunteers Council (ANVC), demanding for separate Garo land whereas the HNLC aims at converting Meghalaya as a province exclusively for the Khasi tribe and free it from "domination" by the Garo tribe. The only case of indigenous insurgency movement in Arunachal Pradesh was the rise of the Arunachal Dragon Force (ADF), which was rechristened as East India Liberation Front (EALF) in 2001. The outfit remained active in the Lohit district, before being neutralized by the state police forces. New insurgency outfit 
called “United People's Democratic Front” was floated in 2011, formed by a former member of Dawood Ibrahim gang, SumonaMunlang [29]. The main objective of the outfit is to create an autonomous district council (ADC) out of nine circles in Lohit and Changlang districts of the state. It is believed that the hard-line faction of the ULFA was playing a key role in the growth of the new outfit [30].

\section{Territorial Ideology, Ethno-Nationalism, Homeland and the Bases of Territorialism}

"No matter how barren, no territory is worthless if it is a homeland. Homeland contains the fundamental of culture and identity; it is special category of territory: it is not an object to be exchanged but an indivisible attribute of group of identity" [31]. This concept encapsulates the entire political movements of different ethnic groups in Northeast India. The constructs of homeland became popular after the independence of India, contradictory with each ethnic group attempts to construct homeland on ethnic line. Contemporary conflicts are deeply rooted in territorial and ethno-nationalism ideology. Homeland principle is the idea that people with deep roots and a historical attachment to the land have a right to control. To the ethnic minority, control over the homeland is vital because it does not only measure relationship between community and resources but also cohesive nature of the community where the strength of the community lies. Increases in territory enhance the power of the community and prove the possession of power by the community. Reorganization of state and breaking them into smaller administrative unit is, therefore, considered as abrasion to their traditional power. They are also apprehensive that losing control of homeland and territory may result to a loss of capacity to reproduce community identity. For ethnic group, territory is a defining attribute of their identity, inseparable from their past and vital to their continued existence as a distinct group [31].

The state looks at territory as indivisible space and often asserts that giving territorial sovereignty to one ethnic group will set a precedent that encourages other ethnic groups to demand self-rule [31]. However, persistence territorial contestation and ethnic conflict are post independent phenomena arising out of the arbitrary demarcation of state's boundaries. After the colonial rule, different territorial entities were lumped together to form new administrative and political units—or states [4] without the approval of the people themselves. The territorial/administrative logic behind the state reorganization and creation of new administrative unit(s) of modern India, seemingly overrides the traditional concept of territory, has broken the historical bond of social relations among the indigenous communities. Redistribution of ethnic population following the reorganization of states (territories) against the well-defined traditional territory sowed the seed of contention and territorial conflict. An ethnic distribution that crosses state boundaries is a source of interstate territorial conflict [32] [33]. For instance, creation of Nagaland state has strong and long repercussions with many Naga inhabited areas are included in different administrative units (Assam, Manipur, Nagaland and Arunachal in India and Myanmar). This has triggered interstate conflict with Naga tribes demanding to bring all the Naga inhabited areas under one administrative umbrella. Similarly, desire of other indigenous population to live under unified homeland/territory remains strong through which their identity can be expressed and within which their mythical places and spaces are located. The politics of "homeland" under various sub-nationalist movements, thus, constitutes a central element in the formation and consolidation of their respective national identities [34].

Territorial politics, revolving around the dichotomy between traditional boundaries (ethnic boundaries) and modern state boundaries, have intensified regional conflict. These boundaries remain central to contemporary conflict with each ethnic community seeks to construct socio-political identity within the traditional territory associated with ethnic setting. The boundaries may be removed or altered or functionally changed, but their existence on the ground constitutes a territorial reality around which political behavior takes place [34]. The existing modern state boundaries, according to them, are artificial boundaries drawn arbitrarily against the wishes of the people. Territorial claims are therefore, invariably couched in terms of recovery of territory that historically belonged to the claiming state/communities. Eventually, it emerges as a main source of conflict because the state is fundamentally a place; its very existence and autonomy are rooted in territory [32].

The politics of territorial identity accompanied by "ethno-nationalism" ideology become popular in Northeast arguably after the emergence of Naga armed resistance movement. The birth of Naga separatist movement not only inspired neighboring communities but also opened the eyes of ethno-political consciousness where "territory” remains the basis of ethno-nationalism. Subsequently, newer separatist movements emerged in Manipur, Assam, Mizoram, Tripura and other parts of the region. The propensity to protect the territory and home com- 
munity arises because all the communities are territorial [3], occupying contiguous geographical landscape. Such ethno-political consciousness and assertions made by different communities have made themselves enemies for one another. Relationship between Meitei and Nagas, Nagas and Kukis, Assamese and Bodos, Garos and Khasis, Bru and Mizos, etc., remains uncertain with intermittent conflict being resurfaced. Slogan for restoration of harmonious coexistence is a far cry with each and every community being busy in putting up their demands for statehood, autonomy, alternative arrangement, special status, so on and so forth.

\section{Contesting State Power Relation, Politics of the Dominants and Armed Insurrection}

The region is romantically labeled as the hot bed of extremism or sensitive [17] infested with varied ethnic armed insurgent groups; range from demanding for autonomy within the constitution of India to full sovereign nation. There are varied causes of armed insurrection and conflict: the significant most being relative deprivation and discontinuous development of the region. These problems are inherently grounded in the structural policies of the state inherited from the colonial regime. Such structural policies give rise to fragmented space characterized by dominant of few core areas leaving the peripheral in distress. A peripheral region far from the core of a state, combination of feelings of deprivation is a powerful force that motivates rebellion [35]. The structural policies, therefore, are perceived as a major source of grievances and conflicts. The repressive policies introduced to extract resources increase angers and resistance of the people. Denial of the right to use conventional politics and protest pushes activists to underground and spawns terrorist and revolutionary resistance [36].

Socio-economic and political development of the region are inherently tied to the mainland India through a series of complex relationship reflecting regional dependency. The economy of the region heavily relies on the import of goods from the mainland. The syndrome of regional economic dependency and Central's apathy towards the region is clearly visible. Regional economic dependency occurs when one regions' economy cannot function effectively without sustenance from other region [37]. Several development programs have been introduced yet in its journey of transition and development, the experiments in the Northeast have consistently failed [38]. Therefore, the paradox of increasing regional tension and conflict alongside introduction of newer schemes for regional development has been often questioned. Relative deprivation, lack of regional integration and discontinuous development have political and economic repercussion, eventually generate forces which set the stage of regional conflict [37]. Failure to integrate with the mainland India politically, economically, socially and lack of recognition towards the people of Northeast India are the most fundamental challenges confronted India. The lack of national integration is rooted in societal divisions, along one or more lines of racial, ethnic, linguistic, religions. In such situation, it is not surprising to find intergroup antagonism and distrusts eventually giving rise to insurrections directed at government [39].

Contemporary spatial development characterized by space of contradiction with varied socio-political and economic dimensions has gained attention of scholars, researchers and policy makers. Such contradictory fragmented spaces are created under new economic system superseding the logic of indigenous mode of production in the pretext of socio-economic transformation. The negligence of the Centre towards development of Northeast India is often cited in the discussion of conflict and underdevelopment of the region. While initiating development plans, it has been always found that the statist version of development policies from the Center came as imposed rather instituting development policies base on the indigenous mode of production. The logic of indigenous way of development, embedded within the rigid social and culture practices, in dissonance with statist development policy eventually intensifies socio-political crisis in Northeast [40]. This new economic system, exaggeratedly emphasizes on market oriented economy with assurance of creations of new jobs and reduction in poverty, favors free enterprises, private capital investment and the extraction of profit from the poor [41]. Under the new economic system, untapped resources are systematically exploited in a large scale in the pretext of transforming the margins, several thousands of poor people are displaced thereby making them victims of development. Rampant exploitation of resources without generating benefit to the people who have in fact given up their lands to the corporate coupled with minimal amount of compensation substantiates powerlessness of the poor population. Simple statement can be that, the region is not neglected but people are neglected and victimized in the pursuit of transforming the region. Negligence by the Centre has resulted to a growing sense of alienation among the people from the mainstream; manifested in various forms of separatist movements in the region. Therefore, contrasting tenet of development approach between the state and the people often resulted to 
conflict when the latter attempt to resist the statist version of development [40]. In this way, the region is doubly displaced within the Constitutional nation-space: as a political-territorial space of the nation, it is still a "periphery", while as a culturally specific locale its difference is misrecognised [42].

Geographical approach of conflict emphasizes on the contested power relation. It is a political violent process through which peoples or groups, who are excluded from power, contest the ruling authority to alter or replace the existing power relationship. The geographic approach to power emphasizes the way in which conflicts and the attempts to resist state power relations are shaped by the particular context of the places in which they occur and, in turn, how the politics of power and resistance create particular space and place-specific politics. In several occasions Nagas in Manipur under the aegis of United Naga Council (UNC) reiterated to oppose any development project that breaches the community's traditional laws and customs. Development projects, such as, construction of dams, oil exploration, demarcation of Special Economic Zones (SEZ) etc., are strongly contested through sending memorandums to the Central government and democratic means. Tribals indeed welcome development programs but not at the cost of losing their customary and traditional laws of land management system; land plays significant role in shaping the culture and ethnic identity. Statist version of development policies often contradicts the traditional system of land management. Contested power relationship takes variety of forms; from localized passive non violent resistance against policies of exclusion to the large scale collective violence of war, which can be conceived "continuum of violence", where the contest between dominating and the resisting power has escalated to the level of insurgency [1]. Insurgency and its related violence and conflicts in Northeast are manifestation of such power relationship.

The longstanding problem of divide between the minority tribals and the dominant non-tribal group is another major issue in Northeast India. Globally, it has been observed that ethnic minorities around the world have recently increased political self-assertion [43], causing waves of conflicts and violence. The discontented minority groups consolidate their stance on slogan: distributive justice against the dictates of the dominant group. The long standing conflicts between Meitei-tribals in Manipur, Mizo-Chakma in Mizoram, Bengali-tribals in Tripura etc., provide appropriate example of dominant-minority relation. These minority groups represent the lower range in the socio-economic strata; often exploited by the dominant group in employment, education, distribution of infrastructure facilities etc. The reactions and counter reactions are severe with often protest by the minority turned violence. In Manipur, United Naga Council (UNC) has severed all ties with the Government of Manipur and demanding for "alternative arrangement". The issues that underlie these conflicts are diverse but clearly tied to the ethnic setting. In general, history of peaceful coexistence of the region is gradually fading away with every community attempts to articulate ethno-political and socio-economic issues on ethnic line. Even the intellectuals and scholars are divided on ethnic line; each tries to justify and see the historical construct of the nation (community) through the lens of their respective historical accounts. Under this hegemonistic regime of the dominant, the oppressed and minority communities opted armed insurrection as the only means to assert their rights.

\section{Conclusion}

The underlying problems, as discussed, in Northeast India have complex and multifaceted dimensions including socio-economic and political aspects. The long standing conflict and violence and the mushrooming newer armed insurrection groups in the region reflect inability of the state to formulate convincing policies. In order to alleviate the problems, it is important to understand the relative deprivation, justification of political action and the balance between discontented people's capacity to act and the government's capacity to redress the plight of the rebellions [36]. The prevailing regional crisis and the measures adopted to alleviate the problems need to be relooked, restructured and reformulated, to promote the practices that serve best for the community. Development from within, through incorporation of the old-age indigenous mode of production in the structural policies, can bring real development in the region. The people feel injustice and treated step motherly comparing with other groups because they are deprived from development benefit. To understand the grievances, it is important to understand ethnicity, culture, political identities of the people and their position in the society. The point is with whom the people identify and in what circumstances does a particular identity become more or less salient to them. The Central's attitude towards the region is equally important since, in many cases, Governmentimposed policies are a major source of grievances and conflicts. How government responds to the political action or the grievances, from which it springs, remain important questions. While seeking to understand and 
respond to popular discontents, it is therefore important to examine the group identities and grievances of the disadvantaged people, including the poor, unemployed, religious and ethnic minorities; understand the source of people grievances by examining their status and their treatment by government and other groups who are more advanced. It is also important to know whether government policies increase or decrease the potential of disruptive conflict; important to study the motives and strategies of government in dealing with disadvantages groups [36]. Government indeed needs to open people's participation for such groups.

\section{References}

[1] Lohman, A.D. and Flint, C. (2010) The Geography of Insurgency. Geography Compass, 4, 1154-1156. http://dx.doi.org/10.1111/j.1749-8198.2010.00361.x

[2] Banerjee-Guha, S. (2011) Contemporary Globalization and the Politics of Space. Economic and Political Weekly, 46, 41-44.

[3] Polk, R.W. (2007) Violent Politics. A History of Insurgency, Terrorism and Guerrilla Warfare. Hay House Publishers India, New Delhi.

[4] Siddiqi, S.R. (2010) Insurgency Movements in India. Failure of the Indian Government to Address the Root Causes Could Lead to a Domino Effect in South Asia. http://axisoflogic.com/artman/publish/Article 61885.shtml

[5] Ahmad, R. (2009) Contesting Geo-Bodies and Rise of Sub-Nationalism in Northeast India: A Case of Nagas and Khasi. Ph.D. Dissertation, Jawaharlal Nehru University, New Delhi.

[6] Kamei, G. (2011) Feudalism in Pre-Colonial Manipur. Dialogue, 12. http://www.asthabharati.org/Dia_Jan\%20011/gang.htm

[7] Scheafer, W. (n.d.) The Economics of Insurgencies: A Framework for Analyzing Contemporary Insurgency Movements with a Focus on Exposing Economic Vulnerability. iSites-Harvard University, Research Paper.

[8] McColl, R.A. (1969) The Insurgent State: Territorial Bases of Revolution. Annals of the Association of American Geographers, 59, 613-631. http://dx.doi.org/10.1111/j.1467-8306.1969.tb01803.x

[9] Bhaumik, S. (2009) Troubled Periphery: Crisis of Indian’s Northeast. Sage Publication, New Delhi. http://dx.doi.org/10.4135/9788132104797

[10] Shimray, T. (2005) Let Freedom Ring: Story of Naga Nationalism. Promilla \& Company Publishers, New Delhi.

[11] Nag, S. (2013) Expanding Imagination: Theory and Praxis of Naga Nation Making in Post Colonial Period. In: Tanweer, F., Ed., Minority Nationalisms in South Asia, South Asian History and Culture, Routledge, New York, 14-34.

[12] Chasie, C. and Hazarika, S. (2009) The State Strikes Back: India and the Naga Insurgency. Policy Studies No. 52, EastWest Center, Washington DC.

[13] Chandola, H. (2013) The Naga Story, First Armed Struggle in India. Chicken Neck, New Delhi.

[14] Lintner, B. (2012) Great Game East. India, China and the Struggle for Asia’s Most Volatile Frontier. Harper Collins, New Delhi.

[15] Welman, F. (2011) Out of Isolation: Exploring and Forgotten World. HPC Publishers and Distributers, New Delhi.

[16] Vashum, R. (2000) Nagas’ Right to Self Determination: An Anthropological Perspective. Mittal Publication, New Delhi.

[17] Dev, N. (2009) The Talking Guns, Northeast India. Manas Publications, New Delhi.

[18] Bharatiya Janata Party (2012) Assam Riot 2012. http://www.bjp.org/images/publications/assam booklet.pdf

[19] Das, S.K. (2007) Conflict and Peace in India’s Northeast: The Role of Civil Society. Policies Studies No.42, East-West Center, Washington DC.

[20] Pudaite, L. (2005) Mizoram. In: Murayama, M., Inoue, K. and Hazarika, S., Eds., Sub-Regional Relations in the Eastern South Asia: With Special Focus on India's North Eastern Region, Joint Research Program Series No.133, 153-240. http://www.ide.go.jp/English/Publish/Download/Jrp/133.html

[21] Bhaumik, S. (2007) Insurgencies in India’s Northeast: Conflict Co-Option and Change. Working Paper No.10, East West Center, Washington DC.

[22] Gosh, B. (2003) Ethnicity and Insurgency in Tripura. Sociological Bulletin, 52, 221-242.

[23] Bhaumik, S. (2012) Tripura: Ethnic Conflict, Militancy and Counterinsurgency, Policies and Practices-52. Mahanirbam Calcutta Research Group. http://www.mcrg.ac.in/PP52.pdf

[24] Phukan, M.D. (2013) Ethnicity, Conflict and Population Displacement in Northeast India. Journal of Humanities and Social Science, 1, 91-101. 
[25] Bhattacharyya, H. (1990) Communism, Nationalism and Tribal Questions in Tripura. Economic and Political Weekly, 25, 2209-2214.

[26] Saha, A. (2005) Tripura. In: Murayama, M., Inoue, K. and Hazarika, S., Eds., Sub-Regional Relations in the Eastern South Asia: With Special Focus on India's North Eastern Region, Joint Research Program Series No.133, $298-317$. http://www.ide.go.jp/English/Publish/Download/Jrp/133.html

[27] Lyngdoh, C.R. and Gassah, L.S. (2003) Decade of Inter-Ethnic Tension. Economic and Political Weekly, 38, 50245026.

[28] Srikanth, H. (2005) Prospects of Liberal Democracy in Meghalaya: A Study of Civil Society’s Response to KSU-Led Agitation. Economic and Political Weekly, 40, 3987-3993.

[29] Mazumdar, P. (2011) Former Dawood Man Forms Militants Outfit in Arunachal Pradesh. http://www.dnaindia.com/india/report-former-dawood-man-forms-militant-outfit-in-arunachal-pradesh-1627457

[30] Choudhury, R.D. (2012) ULFA promoting New Outfit in Arunachal Pradesh. http://www.assamtribune.com/scripts/detailsnew.asp?id=sep2412/at07

[31] Toft, M.D. (2005) The Geography of Ethnic Violence. Identity, Interests and the Indivisibility of Territory. Princeton University Press, Princeton.

[32] Murphy, A.B. (1990) Historical Justification for Territorial Claims. Annals of the Association of American Geographers, 80, 531-548. http://dx.doi.org/10.1111/j.1467-8306.1990.tb00316.x

[33] Murphy, A.B. (2005) Territorial Ideology and Interstate Conflict Comparative Consideration. In: Flint, C., Ed., Geography of War and Peace, Oxford University Press, New York, 281-296.

[34] Newman, D. (2005) Conflict at the Interface, the Impact of Boundaries and Borders on Contemporary Ethno-National Conflict. In: Flint, C., Ed., The Geography of War and Peace, Oxford University Press, New York, 321-344.

[35] O’Loughlin, J. (2005) The Political Geography of Conflict, Civil War in the Hegemonic Shadow. In: Flint, C., Ed., The Geography of War and Peace, Oxford University Press, New York, 85-109.

[36] Gurr, T.R. (2011) Why Men Rebel. Paradigm Publishers, London.

[37] Bookman, Z.M. (1991) The Political Economy of Discontinuous Development, Regional Disparities and Inter-Regional Conflict. Praeger Publishers, New York.

[38] Bhattacharya, R. (2011) Development Disparities in Northeast India. Cambridge University Press India, New Delhi.

[39] O’Neil, B.E. (2005) Insurgency and Terrorism: From Revolution to Apocalypse. Potomac Books, Washington DC.

[40] Khamrang, L. (2013) Contemporary Politics of Development and Spatial Conflict in Northeast India. Proceedings of the International Conference Geography of Change: Contemporary Issue in Development, Environment and Society, Thane, 11-12 January 2013, 153-164.

[41] Peet, R. (2005) Geography of Power, the Making of Global Economic Policy. Zed Book, London.

[42] Biswas, P. (2012) Re-Imagining India’s Northeast: Beyond Territory and State. Journal of North East India Studies, 2, 68-78.

[43] Yiftachel, O. (1997) The Political Geography of Ethnic Protest: Nationalism, Deprivation and Regionalism among Arabs in Israel. Transaction of Institute British Geographer, 22, 91-110. 